\title{
A Study to Replace Existing Causeway to Bridge at Sathy - Periyakodiveri - Kadambur Road
}

\author{
Loganayagan.S ${ }^{1}$, Mahesh. $V^{2}$, Karthiga @ Shenbagam.N ${ }^{3}$, Ramesh. A. $\mathrm{S}^{4}$, \\ Chandra Mohan. $\mathrm{N}^{5}$ \\ ${ }^{*}, 2,3,4,5$ Assistant Professor, Bannari Amman Institute of Technology, Sathyamangalam, Erode District-638401
}

\begin{abstract}
With the advent of science and technology there is a rapid growth in all the fields in the world. The innovations in the various fields are making the world a better mobility to the people. These technological booms have moved the field of structural engineering in leaps and bounds. This project deals with the analysis of multi span simply supported bridge and design of bridge structure manually. This high level bridge is designed as the proposal for replacement of the existing causeway located at Sathyamanagalam Periyakodiveri road.

The main objective of the project is to analysis and design of the entire structure comprising of foundation, deck slab and pier etc. Calculation of total span and height of the bridge based on linear water way and high flood level. To Design the deck slab based on IRC loading conditions and enhance the various features of the bridge.

Keywords: Bridges, Pavement, RCC continuous girder bridges, Causeway.
\end{abstract}

\section{Introduction}

A bridge is a structure providing passage over an obstacle without closing the way beneath. The required passage may be for a road, a railway, pedestrians, a canal or a pipeline. The obstacle to be crossed may be a river, a road, railway or a valley. In other words, bridge is a structure for carrying the road traffic or other moving loads over a depression or obstruction such as channel, road or railway. A bridge is an arrangement made to cross an obstacle in the form of a low ground or a stream or a river without closing the way beneath.

The bridge structure comprises of the following parts.

\section{Superstructure or Decking}

This includes slab, girder, truss, etc. This bears the load passing over it and transmits the forces caused by the same to the substructures.

\section{Bearings}

The bearings transmit the load received from the decking on to the substructure and are provided for distribution of the load evenly over the substructure material which may not have sufficient bearing strength to bear the superstructure load directly.

\section{Substructure}

This comprises piers and abutments, wing walls or returns and their foundation.

Piers and Abutments

These are vertical structures supporting deck/bearing provided for transmitting the load down to the bed/earth through foundation.

\section{$>\quad$ Wing walls and Returns}

These are provided as extension of the abutments to retain the earth of approach bank which otherwise has a natural angle of repose.

\section{Foundation}

This is provided to transmit the load from the piers or abutments and wings or returns to and evenly distribute the load on to the strata. This is to be provided sufficiently deep so that it is not affected by the scour caused by the flow in the river and does not get undermined. While the above mentioned are structurally operational parts, for safety hand rails or parapets, guard rails or curbs are provided over the decking in order to prevent vehicle or user from falling into the stream or for the separation of traffic streams.

In continuous bridges spans are continuous over two or more supports. They are statically indeterminate structures. They are useful when uneven settlement of supports does not take place. In continuous bridges the bending moment anywhere in the span is considerably less than that in case of simply supported span. Such reduction of bending moment ultimately results in the economic section for the bridge. 
In continuous bridges the stresses are reduced due to negative moments developed at pier or supports. Thus continuous span bridges have considerable saving compared to simply supported bridge construction.

In this study, the design, analysis of bridge is confined to replace existing causeway to propose a bridge in Sathy - Periyakodiveri - Kadambur Road.

\section{Study Objective}

- The main objective of this work is to provide a Multi Span bridge over the causeway of width 7.6m. The structure is designed for transportation of the agricultural and industrial products to the nearby industries and access to educational, medical and other commercial activities

- This road is an important Major District road connecting Sathyamanagalam and Kadambur towns crossing important agriculture and marketing centres of Komarapalayam, Kodivery, D.G.Puthur, etc.

- The traffic intensity of this road is very high. The existing causeway is submerged during rainy season and the people of surrounding villages and school going children are put into much hardship due to inundation of flow.

- The crossing being a jungle stream brings heavy water due to sudden downpour in Kadambur and Sathy hills. Hence frequent loss of human life occurs as people tend to risk crossing the overflowing causeway. Hence construction of a bridge in lieu of this causeway is very essential.

III. Study Methodology

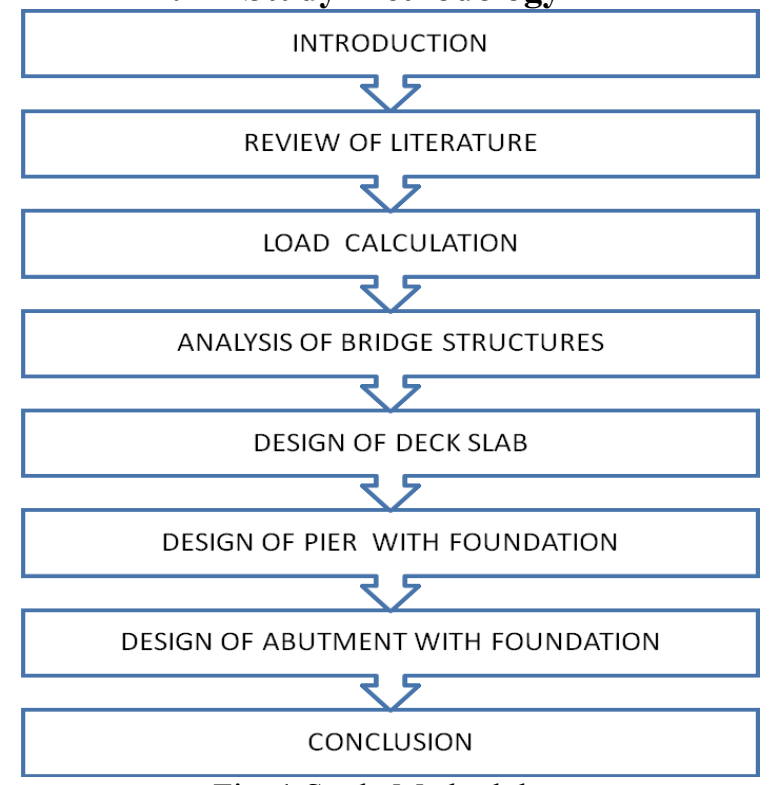

Fig. 1 Study Methodology

\section{GENERAL PROPOSAL OF BRIDGE}

- A number of simply supported girder spans.

- A combination of girders provided with cantilevers and short spans supported by these cantilevers.

- Continuous girders supported by independent piers.

- The following tables gives the proposed specifications of a bridge

Table 1 General Requirement of Bridge

\begin{tabular}{|l|l|}
\hline Type of Bridge & A Skew Bridge. \\
\hline $\begin{array}{l}\text { Type of } \\
\text { Superstructure }\end{array}$ & $\begin{array}{l}\text { Vibrated RCC simply supported solid } \\
\text { deck slab(M25) }\end{array}$ \\
\hline Type of sub-structure & $\begin{array}{l}\text { Abutment and pier are in Vibrated } \\
\text { Cement Concrete M20 Nominal Mix }\end{array}$ \\
\hline Type of Foundation & $\begin{array}{l}\text { Open foundation in Vibrated Cement } \\
\text { Concrete M15 grade Nominal Mix for } \\
\text { Abutment and Pier. }\end{array}$ \\
\hline Clear Span & $7.60 \mathrm{~m}$ clear \\
\hline Number of spans & 5 \\
\hline Skew angle if any & 45 \\
\hline Design of Loading & $70 \mathrm{R}-$ one lane / class A-2 lanes \\
\hline Carriage way & $11.00 \mathrm{~m}$ \\
\hline
\end{tabular}




\begin{tabular}{|l|l|}
\hline Overall Width & $12.00 \mathrm{~m}$ without footpath $(11.00+2 \times 0.50)$ \\
\hline Camber & $2.5 \%$ \\
\hline Sill level & + RL 94.60 \\
\hline MFL & + RL 97.40 \\
\hline Afflux & $0.15 \mathrm{~m}$ \\
\hline Vertical clearance & $0.900 \mathrm{~m}$ \\
\hline Depth of deck slab & $\begin{array}{l}0.700 \mathrm{~m} \text { at centre and } 0.550 \mathrm{~m} \text { at the } \\
\text { edges }\end{array}$ \\
\hline Wearing coat & $0.075 \mathrm{~m}$ \\
\hline $\begin{array}{l}\text { Bottom of } \\
\text { Foundation }\end{array}$ & + RL 91.60 \\
\hline Road level & RL 99.485 \\
\hline
\end{tabular}

\section{Study Area}

The proposed bridge is located at km 0/4 of Sathy - Periyakodivery - Kadambur Road within the jurisdiction of Sathyamangalam $(\mathrm{H})$ sub division of Gobi $(\mathrm{H})$ Division. This road is classified as MDR. This road branches at Km 0/8 of Sathy - Athani- Bhavani Road.

The bridge site is located in a plain terrain and it is away from Sea Shore. Hence the structural components of the bridge are designed for Moderate Exposure from durability consideration.

There exists a Piped causeway. This consists of two rows of $900 \mathrm{~mm}$ dia pipes in Skew crossing. The causeway is located in a dip portion and its road level lies more than $2 \mathrm{~m}$ below the existing road level in approaches. This Causeway lies about $150 \mathrm{~m} \mathrm{D} / \mathrm{S}$ of the bridge at Sathy - Athani - Bhavani road.

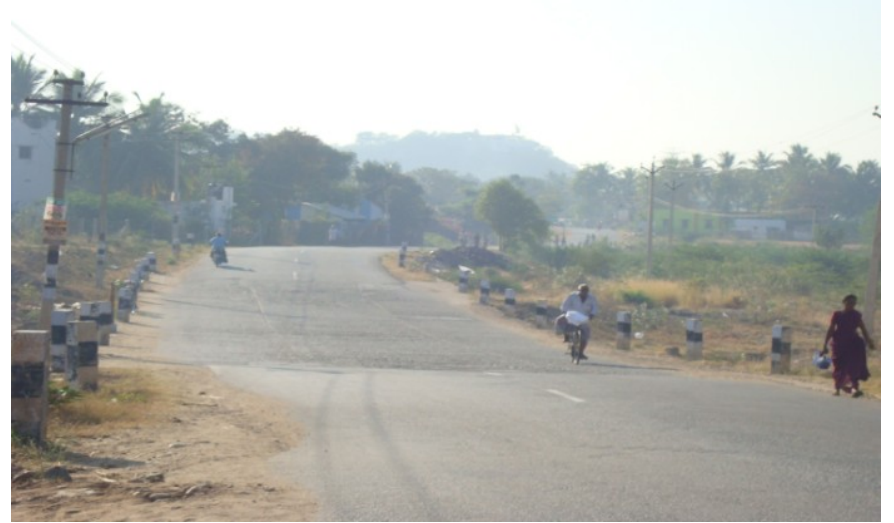

Fig.2. Study Area (Front view)

The Alignment follows the existing road alignment and it is skew crossing of $45 \mathrm{deg}$. The discharge worked out by area - velocity method is tabulated above. Taking maximum discharge of $299.482 \mathrm{~m} / \mathrm{sec}$ at 50 $\mathrm{U} / \mathrm{S}$ as design discharge and velocity of $3.778 \mathrm{~m} / \mathrm{sec}$ as design velocity, the Linear Waterway works out to $35.412 \mathrm{~m}$.Hence it is proposed 5 Spans of $7.6 \mathrm{~m}$ clear.

As per the subsoil investigation soft rock is available at the ground level for a depth of $3.00 \mathrm{~m}$. considering the high strength subsoil available for a considerable depth from the sill level, open foundation is proposed.

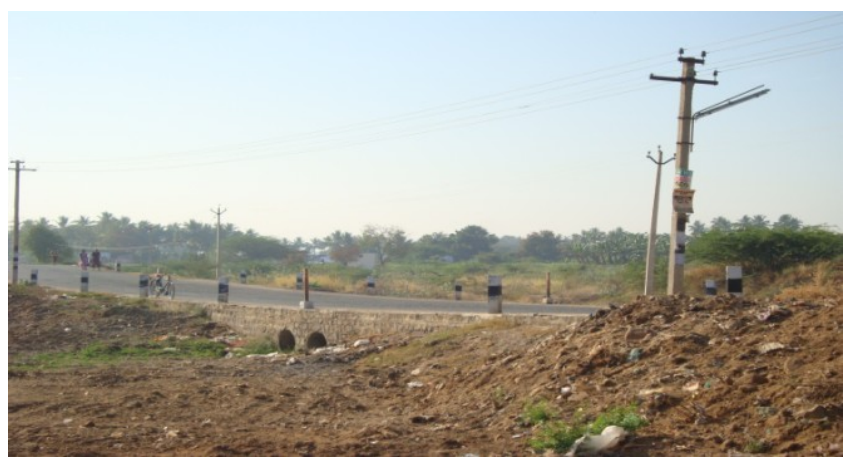

Fig.3. Study Area (side view) 


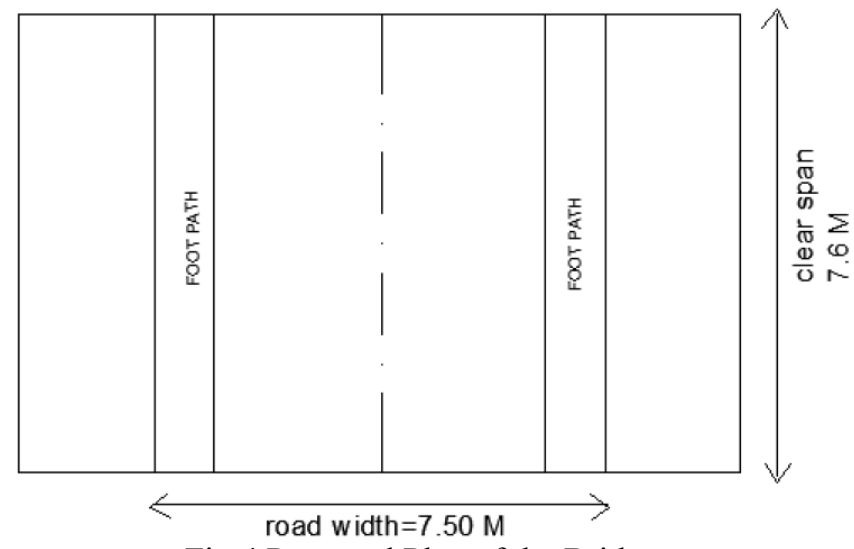

Fig.4 Proposed Plan of the Bridge

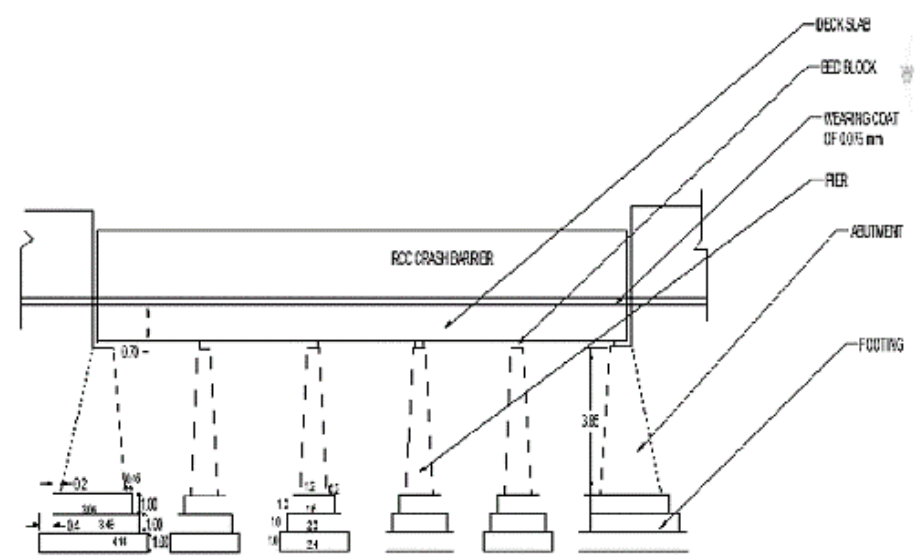

Fig.5 Proposed Section of the Bridge

\section{Design And Analysis Of Structure}

For designing and analysis the following codes were referred

$>$ Code of practice for design loads for buildings and structures

- IS: 875 Part - 1 (Dead load)

- IS: 875 Part - 2 (Live load)

- IS: 875 Part - 3 (Wind load)

$>$ Plain and reinforced concrete -code of practice

- IS: $456: 2000$

$>$ Code of practice for design load for bridges

- $\quad$ IRC 5 -1998,

- $\quad$ IRC $6-2010$,

- $\quad$ IRC $21-2000$,

- $\quad$ IRC $78-2000$.

\section{Design Of DeCK Slab}

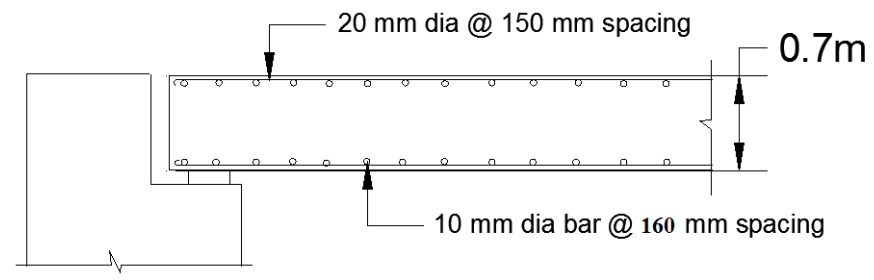

Fig 5.1 Cross Section of Deck Slab 


\section{LOAD ANALYSIS}

The load analysis is done by single span loading condition and two span loading conditions. In both the type considering three case

\subsection{SINGLE SPAN LOADING CONDITION}

CASE I: 70 R WHEELED VEHICLE

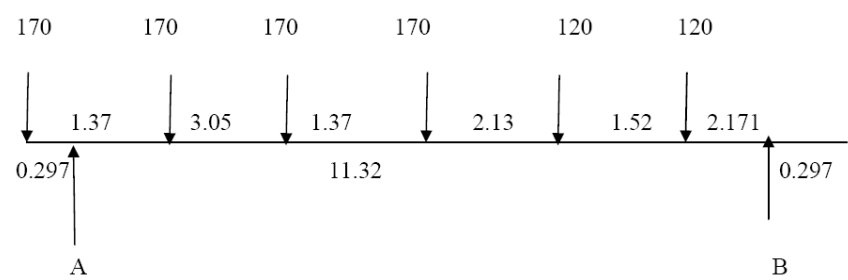

CASE II: 70R TRACKED VEHICLE

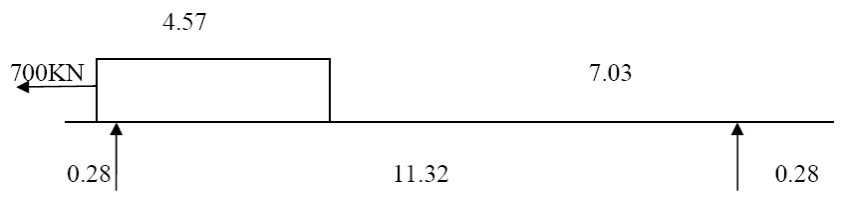

CASE III: CLASS A WHEELED VEHICLE

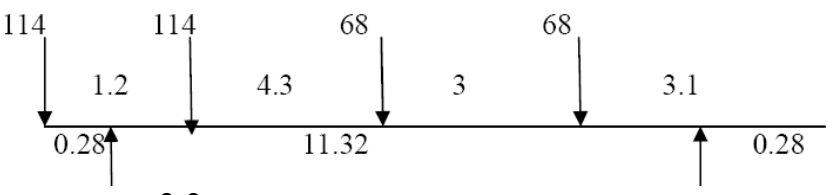

2.2 TWO SPAN LOADING CONDITION

CASE I: 70 R WHEELED VEHICLE

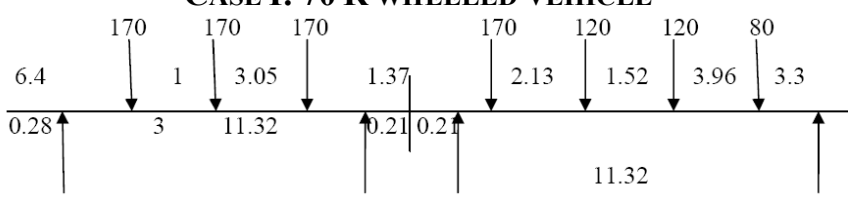

A B

CASE II: 70R TRACKED VEHICLE

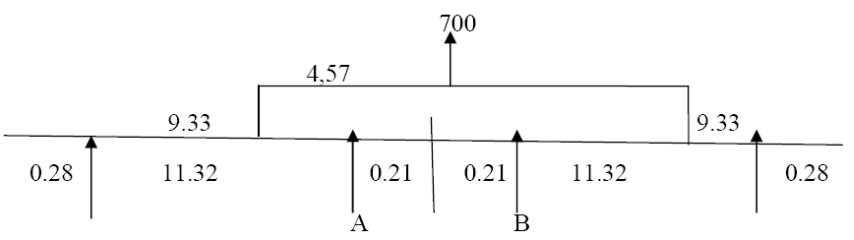

CASE III: CLASS A WHEELED VeHiCle

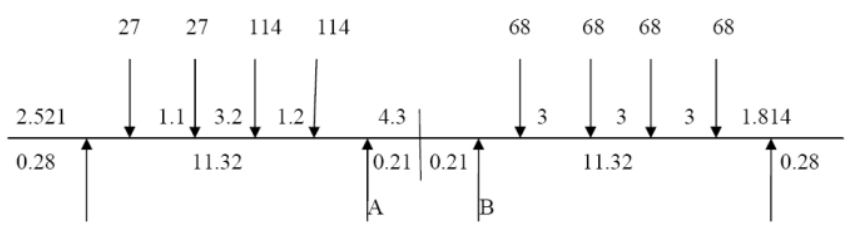

\subsection{CALCULATION OF IMPACT FACTOR}

CASE I: CLASS A WHEELED VEHICLE

CASE II: CLASS AA WHEELED VEHICLE

CASE III: CLASS AA WHEELED VEHICLE

\section{DESIGN OF PCC ABUTMENT}

The abutment design includes the following parameters such as

- Loads

- Geometry data

- Soil parameters

- Material data 
- Design notes

- Dead load from the structure

- Live load from super structure

- Vertical reaction induced due to braking force

- Longitudinal force cum frictional force resistance:

- Active earth pressure

- For vertical face

- For sloped face

- At foundation

- Vertical face of abutment

- Inclined face of abutment

- Check for fluid pressure

The self weights considered and their results are tabulated below

Table 2 Self Weights

\begin{tabular}{|l|l|l|l|}
\hline \multicolumn{1}{|c|}{ DESCRIPTION } & $\begin{array}{l}\text { SELF } \\
\text { WEIGHT }\end{array}$ & $\begin{array}{c}\text { LEVER } \\
\text { ARM(m) }\end{array}$ & MOMENT(KNm) \\
\hline $\begin{array}{l}\text { Front batter - } \\
(1 / 2) \times 3.85 \times 30 \times 0.385\end{array}$ & 22.23 & 0.25 & 5.56 \\
\hline $\begin{array}{l}\text { Below bed block - } \\
0.425 \times 30 \times 3.85\end{array}$ & 49.08 & 0.59 & 28.96 \\
\hline Below dirt wall $-0.3 \times 3.85 \times 25$ & 28.875 & 0.95 & 27.43 \\
\hline Rear batter $-(1 / 2) \times 3.85 \times 25 \times 1.28$ & 61.6 & 1.5 & 92.4 \\
\hline Bed block $-0.7 \times 25 \times 0.25$ & 4.375 & 0.72 & 3.15 \\
\hline Dirt wall $-0.7 \times 25 \times 0.3$ & 5.25 & 0.95 & 4.99 \\
\hline
\end{tabular}

Table 3 Result of PCC design Abutment

\begin{tabular}{|l|l|}
\hline DESCRIPTION & VALUES \\
\hline Active earth pressure & \\
\hline at verticle face & 0.2445 \\
\hline at sloped face & 0.3943 \\
\hline at foundation & 0.2445 \\
\hline Moment due to flud pressure & \\
\hline at vertical face & $26.77 \mathrm{KNm}$ \\
\hline at sloped face & $58.33 \mathrm{KNm}$ \\
\hline Vertical reaction induced due to braking & \\
\hline Intensity of vertical reaction & $63.4 \mathrm{KN}$ \\
\hline Moment due to this reaction & $2.07 \mathrm{KNm}$ \\
\hline
\end{tabular}

4. ABUTMENT PRESSURE CALCULATION AT FOUNDATION LEVEL

The parameters considered for abutment pressure calculation at foundation level are mentioned below

- Stress due to the dead load super structure

- Stress due to the live load super structure

- Stress due to the vertical reaction due to the braking

- $\quad$ Stress due to the longitudinal force

- Stress due to buoyancy

- Active earth pressure calculation

- Stress due to fluid pressure

- Passive earth pressure @ foundation level

- Check for stability@ foundation level 
Considering span loaded condition

- Check for sliding

- Check for overturning

Considering span no loaded condition

- Check for sliding

- Check for overturning

Check for Stability Under Dislodged Condition

- Check for sliding

- Check for overturning

The analysis and design of abutment is based on the following IRC codes

- IRC :5-199

- IRC :6-2010

- IRC :78-2000

- IRC : $112-2010$

Table 4 Moment Calculations

\begin{tabular}{|c|c|c|c|}
\hline Description & WEIGHT/m & LEVER ARM & MOMENT \\
\hline $\begin{array}{l}\text { Front batter } \\
\qquad(1 / 2) * 3.85 * 0.385 * 25\end{array}$ & 18.52 & 1.60 & 29.6937 \\
\hline $\begin{array}{l}\text { Below bed block } \\
\qquad 0.425 * 0.385 * 25\end{array}$ & 40.91 & 1.94 & 79.3654 \\
\hline $\begin{array}{l}\text { Below dirt wall } \\
\qquad 0.3 \times 3.85 \times 25\end{array}$ & 28.88 & 2.30 & 66.4240 \\
\hline $\begin{array}{l}\text { Rear batter } \\
\quad 0.5 \times 3.85 \times 1.28 \times 25\end{array}$ & 61.6 & 2.85 & 175.56 \\
\hline $\begin{array}{l}\text { Bed block } \\
\qquad 0.7 \times 0.25 \times 25\end{array}$ & 4.38 & 2.07 & 9.066 \\
\hline $\begin{array}{l}\text { Dirt wall } \\
\qquad 0.7 \times 0.3 \times 25\end{array}$ & 5.25 & 2.3 & 12.07 \\
\hline $\begin{array}{l}\text { Earth over rear batter triangular portion } \\
0.5 \times 1.2 \times 3.85 \times 18\end{array}$ & 41.58 & 3.25 & 135.1350 \\
\hline $\begin{array}{l}\text { Earth over rear batter rectangular portion } \\
\quad 1.2 \times 1.025 \times 18\end{array}$ & 22.14 & 3.05 & 67.527 \\
\hline $\begin{array}{l}\text { Earth over footing } 1 \text { rear side } \\
0.2 \times 4.88 \times 18 \\
\end{array}$ & 17.57 & 3.75 & 65.88 \\
\hline $\begin{array}{l}\text { Earth over footing } 2 \text { rear side } \\
0.2 \times 6.88 \times 18\end{array}$ & 24.77 & 3.95 & 97.84 \\
\hline $\begin{array}{l}\text { Earth over footing } 1 \text { front side } \\
\qquad 1 \times 0 \times 18\end{array}$ & 0 & 0.675 & 0 \\
\hline $\begin{array}{l}\text { Earth over footing } 2 \text { front side } \\
0.45 \times 1 \times 18\end{array}$ & 8.1 & 0.225 & 1.8225 \\
\hline $\begin{array}{l}\text { Wt.of cc footing } 1 \text { below sill } \\
3.04 \times 1 \times 25\end{array}$ & 76 & 2.375 & 180.5 \\
\hline $\begin{array}{l}\text { Wt. of cc footing } 2 \text { below sill } \\
3.49 \times 1 \times 25\end{array}$ & 87.25 & 2.15 & 187.58 \\
\hline $\begin{array}{l}\text { Wt.of cc footing } 3 \text { below sill } \\
4.14 \times 1 \times 25\end{array}$ & 103.5 & 2.025 & 209.587 \\
\hline Total & 540.45 & & 1318.07 \\
\hline
\end{tabular}

Table 5 Summary of Stress

\begin{tabular}{|l|l|l|l|l|}
\hline \multicolumn{1}{|c|}{ DESCRIPTION } & \multicolumn{2}{|l|}{ SPAN LOADED CONDITION } & \multicolumn{2}{l|}{ SPANUNLOADED CONDITION } \\
\cline { 2 - 5 } & & -11.98 & 18.08 & -11.98 \\
\hline $\begin{array}{l}\text { Dead load from super } \\
\text { structure }\end{array}$ & 18.08 & -4.98 & 0 & 0 \\
\hline $\begin{array}{l}\text { Live load from super } \\
\text { structure }\end{array}$ & 7.51 & -0.56 & 0 & 0 \\
\hline $\begin{array}{l}\text { Vertical reaction due to } \\
\text { braking }\end{array}$ & 0.84 & -76.17 & 76.17 & -76.17 \\
\hline Longitudinal force friction & 76.17 & -159.84 & 246.36 & -246.36 \\
\hline $\begin{array}{l}\text { Earth pressure \& live load } \\
\text { surcharge } \\
\text { Self wt. }\end{array}$ & 159.84 & 200.55 & 60.5 & 200.55 \\
\hline Total stress dry condition & 60.54 & -3.87 & -3.87 & -3.87 \\
\hline Buoyancy effect & -3.87 & 49.11 & 397.28 & 130.09 \\
\hline Total stress wet condition & 319.11 & & \\
\hline
\end{tabular}




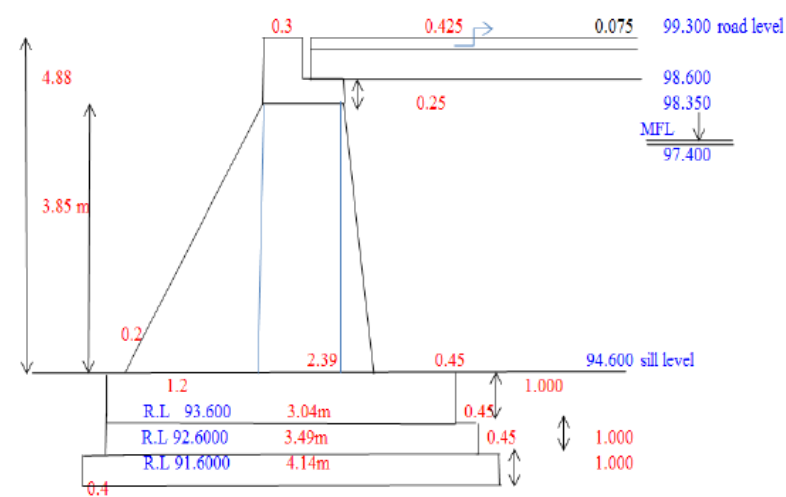

Fig. Cross Section of Abutment with Footing

Table 6 Results of Abutment Pressure Calculations

\begin{tabular}{|c|l|c|c|}
\hline & SLIDING & OVER TURNING & REMARKS \\
\hline CONDITION & & & \\
\hline Span loaded & $1.51>1.50$ & $1.62>1$ & Safe \\
\hline & & & \\
\hline Span no loaded & $1.62>1.50$ & $1.56>1$ & Safe \\
\hline & & & \\
\hline Dislodged & $1.6>1.50$ & $2>1$ & Safe \\
\hline & \multicolumn{3}{|l}{} \\
\hline
\end{tabular}

\section{DESIGN OF PCC PIER} tabulated.

The PCC Pier design includes various forces and moments acting on it and respective results are

Table 7 Summary of Forces and Moments at Top of Footing

\begin{tabular}{|c|c|c|c|c|c|c|c|}
\hline \multirow[t]{2}{*}{ S.NO } & \multirow{2}{*}{$\begin{array}{l}\text { LOAD } \\
\text { FACTOR }\end{array}$} & \multirow{2}{*}{$\begin{array}{l}\text { DESCRIPTION OF } \\
\text { LOADING }\end{array}$} & \multirow{2}{*}{$\begin{array}{l}\text { DIRECT } \\
\text { LOAD } \\
\text { P(KN) }\end{array}$} & \multicolumn{2}{|c|}{ Longitudinal } & \multicolumn{2}{|c|}{ Transverse } \\
\hline & & & & $\begin{array}{l}\mathrm{HL} \\
(\mathrm{KN})\end{array}$ & $\begin{array}{l}\text { ML } \\
(\mathrm{KNm})\end{array}$ & $\begin{array}{l}\mathrm{HT} \\
\text { (KN) }\end{array}$ & $\begin{array}{l}\text { MT } \\
(\mathrm{KNm})\end{array}$ \\
\hline 1 & 1.35 & $\begin{array}{l}\text { D.L+Super imposed } \\
\text { D.L }\end{array}$ & 172.063 & 0.000 & 0.000 & 0.000 & 0.000 \\
\hline 2 & 1.75 & Wearing coat & 24.470 & 0.000 & 0.000 & 0.000 & 0.000 \\
\hline 3 & 1.5 & Wt. of substructure & 152.077 & 0.000 & 0.000 & 0.000 & 0.000 \\
\hline 4 & & $\begin{array}{l}\text { One span loaded } \\
\text { condition }\end{array}$ & & & & & \\
\hline a) & 1.5 & $\begin{array}{l}\text { L.L from } \\
\text { superstructure }\end{array}$ & 69.287 & 0.000 & 14.550 & 0.000 & 0.000 \\
\hline b) & 1.5 & $\begin{array}{l}\text { Horizontal force due } \\
\text { to braking }\end{array}$ & 5.088 & 0.000 & 1.068 & 0.000 & 0.000 \\
\hline c) & 1.5 & $\begin{array}{l}\text { Long. Force dueto } \\
\text { frictional resistance }\end{array}$ & 0.000 & 15.609 & 64.151 & 0.000 & 0.000 \\
\hline 5 & & $\begin{array}{l}\text { Two span loaded } \\
\text { condition }\end{array}$ & & & & & \\
\hline a) & 1.5 & $\begin{array}{l}\text { L.L from } \\
\text { superstructure }\end{array}$ & 13.178 & 0.000 & 2.767 & 0.000 & 0.000 \\
\hline b) & 1.5 & $\begin{array}{l}\text { Vertical reaction } \\
\text { induced braking }\end{array}$ & 0.651 & 0.000 & 0.137 & 0.000 & 0.000 \\
\hline c) & 1.5 & Long.force cum & 0.000 & 13.329 & 54.784 & 0.000 & 0.000 \\
\hline
\end{tabular}

\begin{tabular}{|c|c|c|c|c|c|c|c|}
\hline & & frictional resistance & & & & & \\
\hline 6 & 1.15 & Wind force & 0.000 & 3.673 & 15.986 & 0.810 & 2.431 \\
\hline 7 & 1.00 & Water current & 0.000 & 0.000 & 0.000 & 1.100 & 1.839 \\
\hline 8 & & Cross current & 0.000 & 9.900 & 116.580 & 0.000 & 0.000 \\
\hline \multicolumn{8}{|c|}{ Total force and moment under dry condition } \\
\hline & & \begin{tabular}{|l|} 
Under one span \\
loaded condition
\end{tabular} & 226.45 & 0.000 & 148.18 & 0.000 & 0.000 \\
\hline & & $\begin{array}{l}\text { Under two span } \\
\text { loaded cndition }\end{array}$ & 165.91 & 0.000 & 190.25 & 0.000 & 0.000 \\
\hline 9 & 1.00 & buoyancy & -20.421 & 0.000 & 0.000 & 0.000 & 0.000 \\
\hline \multicolumn{8}{|c|}{ Total force and moment under wet condition } \\
\hline & & \begin{tabular}{|l|} 
Under one span \\
loaded condition
\end{tabular} & 206.03 & 0.000 & 148.18 & 0.000 & 0.000 \\
\hline & & $\begin{array}{l}\text { Under two span } \\
\text { loaded condition }\end{array}$ & 145.48 & 0.000 & 190.25 & 0.000 & 0.000 \\
\hline 5 & & $\begin{array}{l}\text { Vertical reaction due } \\
\text { t braking }\end{array}$ & 0.00 & 0 & 0.000 & 0 & 0 \\
\hline 6 & & Earth pressure active & 0.00 & 0 & 0.000 & 0 & 0 \\
\hline 7 & & L.L surcharge & 0.00 & 0.00 & 0.000 & 0 & \\
\hline 8 & & $\begin{array}{l}\text { Wt.due to braking } \\
\text { \&shrinkage }\end{array}$ & 0.00 & 0 & 0.000 & 0 & 0 \\
\hline 9 & & Self wt. & 0.00 & 0 & 0.000 & 0 & 0 \\
\hline 10 & & Buoyancy & 0.00 & 0 & 0.000 & 0 & 0 \\
\hline
\end{tabular}


6. PIER PRESSURE CALCULATION AT FOUNDATION LEVEL

The Pier Pressure calculation at foundation level loading conditions is tabulated.

Table 8 Summary of Loading Conditions

\begin{tabular}{|c|c|c|c|c|c|}
\hline \multirow[t]{2}{*}{ S.No } & \multirow[t]{2}{*}{ Description of loading } & \multicolumn{2}{|c|}{ Under dry condition } & \multicolumn{2}{|c|}{ Under wet condition } \\
\hline & & a & a & a & (a) \\
\hline & Stresses due to & $\mathrm{KN} / \mathrm{sqm}$ & $\mathrm{KN} / \mathrm{sqm}$ & $\mathrm{KN} / \mathrm{sqm}$ & $\mathrm{KN} / \mathrm{sqm}$ \\
\hline 1 & & 154.801 & 154.801 & 154.801 & 154.801 \\
\hline 2 & Two span loaded condition & & & & \\
\hline $\bar{A}$ & L.L from superstructure & 27.442 & 23.884 & 27.4442 & 23.884 \\
\hline B & $\begin{array}{l}\text { Vertical reaction due to } \\
\text { braking }\end{array}$ & 0.255 & 0.079 & 0.255 & 0.079 \\
\hline $\mathrm{C}$ & Long. Force cum friction & 71.342 & -71.34 & 71.342 & -71.34 \\
\hline 3 & One span loaded condition & & & & \\
\hline A & L.L from superstructure & 27.170 & 8.643 & 27.170 & 8.643 \\
\hline B & Vertical force due to braking & 1.411 & 0.439 & 1.411 & 0.439 \\
\hline $\mathrm{C}$ & Long.force cum friction & 71.342 & -71.34 & 71.34 & -71.342 \\
\hline 4 & Wind force & 2.972 & -2.972 & 2.052 & -2.052 \\
\hline 5 & Water current & 0.000 & 0.000 & 0.036 & -0.036 \\
\hline 6 & Cross current & 0.000 & 0.000 & 0.964 & -0.964 \\
\hline 7 & Buoyancy effect & 0.000 & 0.000 & -32.448 & -32.448 \\
\hline & Two span loaded condition & 256.813 & 104.452 & 224.445 & 71.924 \\
\hline & One span loaded condition & 257.696 & 89.39 & 225.329 & 56.862 \\
\hline
\end{tabular}

Summary of results at sill level in a chance

Max. stress developed $=257.70 \mathrm{KN} / \mathrm{sqm}$

Min. stress developed $=56.86 \mathrm{KN} / \mathrm{sqm}$

The stresses are well within the permissible limits of the grade of concrete adopted in the design and no tension at foundation level. The maximum pressure developed at the founding strata is well within the safe bearing capacity of soil at the founding level. The section is safe at foundation level and do not require revision.

The stresses are well within the permissible limits of the grade of concrete adopted $\mathrm{n}$ the design and no tension at foundation level. The maximum pressure developed at the founding strata is well within the safe bearing capacity of soil at the founding level. The section is safe at foundation level and do not require revision.

The Summary of Forces and Moment at Top of Footing are tabulated for different conditions.

Table 9 Summary of Forces and Moment at Top of Footing

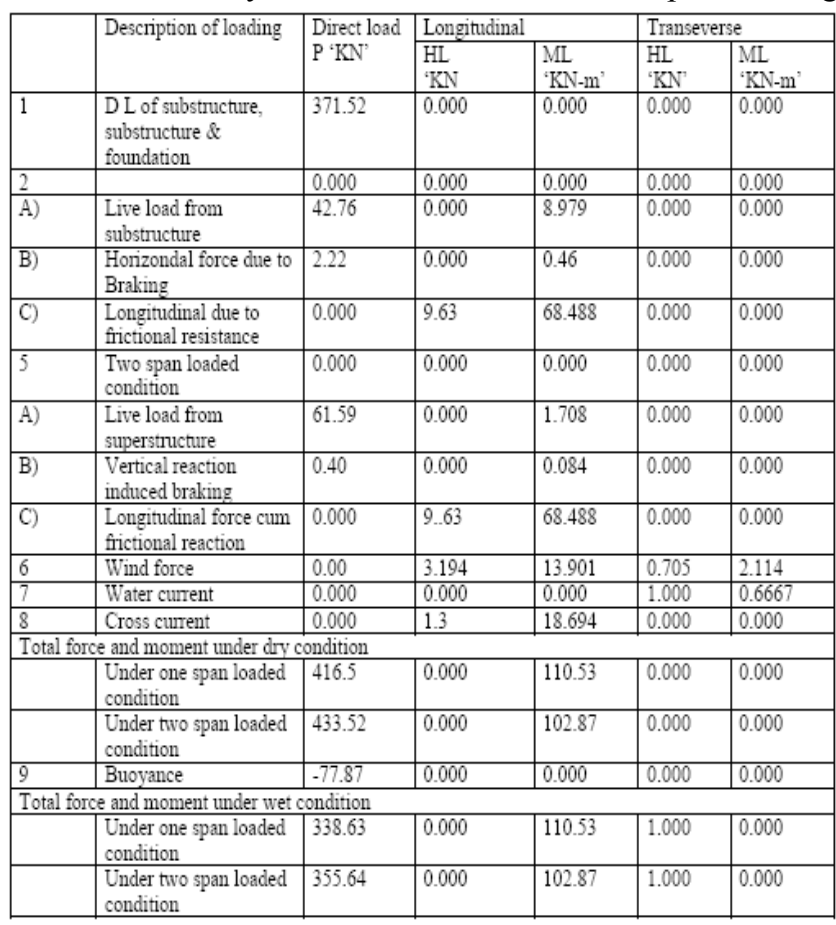




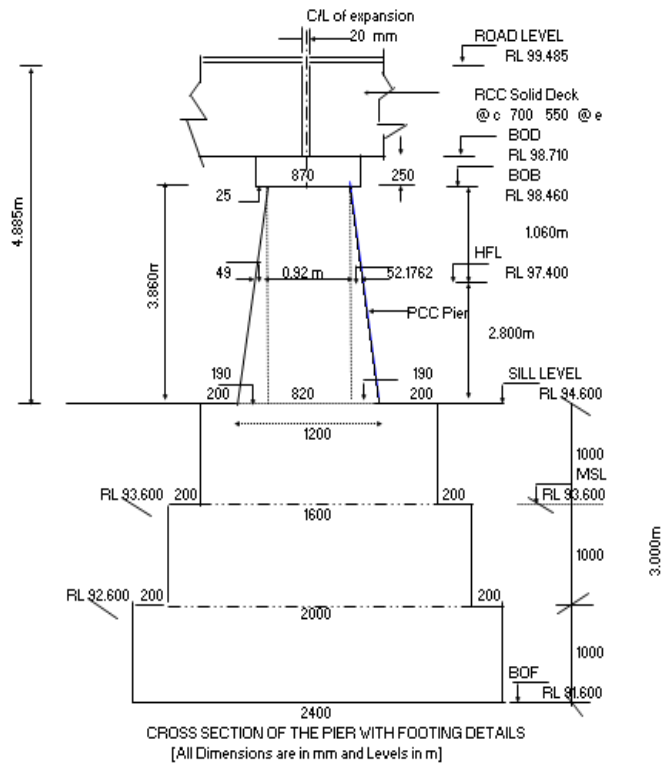

Fig Cross Section Pier with Footing

The stresses are well within the permissible limits of the grade of concrete adopted $\mathrm{n}$ the design and no tension at foundation level. The maximum pressure developed at the founding strata is well within the safe bearing capacity of soil at the founding level. The section is safe at foundation level and do not require revision.

\section{Conclusions And Recommendations}

1. It has been observed that people suffering for their daily trip in rainy season and as well as the causeway may be replaced to bridge, so that it will enhance their locality to reach the city easily and smoothly.

2. For designing a bridge, required factors considered according to Sathy - Periyakodivery - Kadambur road surrounding area and analysed through this study.

3. The complete study has done in point of existing causeway to replace as bridge.

4. Thus, this study further submitted to government for consideration and by keeping view of people welfare it can be recommended for future proposal.

\section{References}

[1]. Standard specification and code of practice for road bridges (IRC :6- 2010)' Published by Indian Road Congress.

[2]. Standard specification and code of practice for road bridges (IRC :6 -2000)' Published by Indian Road Congress

[3]. Indian standard plain and reinforced concrete code of practice (IS 456:2000)' published by Bureau of Indian Standards.

[4]. Limit state design of reinforced concrete'byDr.P.C.Punmia, published by Laxmi publications Pvt.Ltd.

[5]. Continuous prestressed concrete girder bridges' by Mary Beth D.Hueste Published by Texax Transportation Institute.

[6]. Seismic performance of multi span simply supported highway bridge having steel Girders' by Murat Dicleli Published by Elsiver science Ltd.

[7]. Seismic performance of multi span simply supportd slab - on- girder steel high way Bridge' by Michel Bruneau.

[8]. Camber control in simply supported prestressed concrete bridge girders 'by Osamah Ibrahim Mahmood.

[9]. Design of Bridge engineering" by S.Ponnusamy (2nd Edition)

[10]. Design of Bridge engineering" by N.Krishan raju (fourth edition)

[11]. Design of Bridge engineering" by D.Johnson Victor( 6th Edition) 